\title{
Direct Evidence for Ligand-Induced Internalization of the Yeast $\alpha$-Factor Pheromone Receptor
}

\author{
KIMBERLY A. SCHANDEL AND DUANE D. JENNESS* \\ Department of Molecular Genetics and Microbiology, University of Massachusetts Medical School, Worcester, \\ Massachusetts 01655-0122
}

Received 17 June 1994/Returned for modification 7 July 1994/Accepted 3 August 1994

\begin{abstract}
When Saccharomyces cerevisiae a cells bind $\alpha$-factor pheromone, the ligand is internalized and its binding sites are lost from the cell surface in a time-, energy-, and temperature-dependent manner. This report presents direct evidence for $\alpha$-factor-induced internalization of cell surface receptors. First, membrane fractionation on Renografin density gradients indicated that the $\alpha$-factor receptors were predominantly found in the plasma membrane peak before $\alpha$-factor treatment and then appeared in membranes of lesser buoyant density after $\alpha$-factor exposure. Second, receptors were susceptible to cleavage by extracellular proteases before $\alpha$-factor treatment and then became resistant to proteolysis after exposure to pheromone, consistent with the transit of receptors from the cell surface to an internal compartment. The median transit time in both assays was approximately $8 \mathrm{~min}$. The ultimate target of the internalized receptors was identified as the vacuole, since the membranes containing internalized receptors cofractionated with vacuolar membranes, since the turnover of receptors was stimulated by $\alpha$-factor exposure, and since receptor degradation was blocked in a pep4 mutant that is deficient for vacuolar proteases. The carboxy-terminal domain of the receptor that is required for ligand internalization was also found to be essential for endocytosis of the receptor. A receptor mutant, ste2-L236H, which is defective for pheromone response but capable of ligand internalization, was found to be proficient for receptor endocytosis. Hence, separate structural features of the receptor appear to specify its signal transduction and internalization activities.
\end{abstract}

For Saccharomyces cerevisiae, the induction of mating-specific processes is mediated by the exchange of the peptide mating factors that are produced by the two haploid cell types, a and $\alpha$ cells (reviewed in references 39 and 57). a cells secrete the pheromone a-factor, whereas $\alpha$ cells secrete $\alpha$-factor pheromone. Receptors specific for these pheromones are found on the surface of cells of the opposite cell type, i.e., the $\alpha$-factor receptors, encoded by the STE2 gene, are found on a cells (28), whereas the a-factor receptors, encoded by STE3, are found on $\alpha$ cells (24). The binding of either pheromone to its receptor initiates a signal transduction pathway that includes the action of a heterotrimeric $G$ protein $(21,42,62)$ and a protein kinase cascade related to the mitogen-activated protein kinase cascade found in mammalian systems (44). This signal facilitates mating by blocking cell division at $\mathrm{G}_{1}$, stimulating the transcription of several genes that encode matingspecific activities, and inducing morphological changes of the cells. In the absence of mating, the haploid cells adapt to the action of $\alpha$-factor by degrading the pheromone extracellularly $(11,15)$ and by regulating postreceptor events in the response pathway $(4,13,20,34,41,47)$.

DNA sequence analysis of the STE2 and STE3 genes $(8,24$, 43) as well as topological studies of the gene products $(10,18)$ suggest that both receptors contain seven transmembrane domains, an extracellular amino terminus, and a carboxy terminus exposed to the cytoplasm. This structure is characteristic of G-protein-coupled receptors such as rhodopsin and the $\beta$-adrenergic receptors (22). Although the a-factor and $\alpha$-factor receptors activate the same signalling pathway (3),

\footnotetext{
* Corresponding author. Mailing address: Department of Molecular Genetics and Microbiology, University of Massachusetts Medical School, 55 Lake Ave. North, Worcester, MA 01655-0122. Phone: (508) 856-2157. Fax: (508) 856-5920. Electronic mail address: jennessd@ umassmed.ummed.edu.
}

presumably by interacting with a common $\mathrm{G}$ protein $(6,29)$, they share no obvious sequence homology. Mutational studies of the $\alpha$-factor receptor $(17,61)$ and other receptors with a similar structure $(23,32)$ implicate the third cytoplasmic loop in the coupling of these receptors to their respective G proteins. Other mutational analyses indicate that the carboxyterminal cytoplasmic domain of the pheromone receptor is important for receptor down regulation, pheromone internalization, adaptation to the pheromone-induced signal, and pheromone-induced morphological changes $(33,34,47,49)$.

A large body of experimental evidence suggests that pheromones are internalized by receptor-mediated endocytosis. Radioactive $\alpha$-factor becomes associated irreversibly with a cells in an energy- and receptor-dependent manner $(14,30)$. This association is accompanied by a disappearance of ligandbinding sites from the cell surface (30). Clathrin, which plays a major role in receptor-mediated endocytosis in mammalian cells, has recently been shown to facilitate the internalization of $\alpha$-factor (58). Following internalization, the pheromone appears to be translocated to the vacuole via vesicular intermediates (54), which may represent early and late endosomes (55). Although there is no direct evidence that the $\alpha$-factor receptor leaves the cell surface upon binding pheromone, a-factor receptors have been shown to pass from the plasma membrane to the vacuole, and this process is accelerated when $\alpha$ cells are treated with a-factor (19). There is as yet no direct evidence for the internalization of the a-factor ligand.

We sought physical evidence for the ligand-induced endocytosis of the $\alpha$-factor receptor. Three independent criteria were used to establish the movement of $\alpha$-factor receptors from the plasma membrane to internal compartments of the cell. First, Renografin density gradient centrifugation was used to fractionate the cellular membranes, allowing us to follow the ligand-induced exit of the receptor from the plasma membrane upon $\alpha$-factor exposure. Second, protease susceptibility assays 
showed that the receptor became resistant to external protease upon pheromone addition. Third, the destination for the internalized receptors was identified as the vacuole by examining the half-life of the receptor in the presence and absence of vacuolar proteases. The relationship between endocytosis and signal transduction was explored by using receptor mutants exhibiting defects in one of these functions.

\section{MATERIALS AND METHODS}

Strains and plasmids. All strains are congenic to strain $381 \mathrm{G}$ (27). The genotype of strain DJ211-5-3 is MATa cry1 bar1-1 ade2-1 his4-580 leu2 lys2 trp1 tyr1 ura3 SUP4-3. Strain DJ213-7-3 is MATa cry1 bar1-1 ste2-10::LEU2 ade2-1 his4-580 leu2 lys 2 trp1 tyr1 ura3 SUP4-3. Strain DJ900-A, which contains the pep4::URA3 mutation, is a derivative of strain DJ211-5-3. It was constructed by a single-step gene replacement procedure (52) in which strain DJ211-5-3 was transformed with the XhoI-EcoRI fragment from plasmid pTS15 (51) carrying pep4::URA3. The presence of the pep4::URA3 allele was confirmed by PCR analysis. Yeast centromere plasmid pJBK008, which contains $S T E 2$ and $U R A 3$, was described previously (34). Plasmid pDJ252 was constructed by subcloning the ste2-T326 allele from pJBK023 (34) into the yeast integrating vector pDJ251, which contains the URA3 gene. Strain DJ903-A-1 containing ste2-T326 was derived from strain DJ211-5-3 by the two-step gene replacement method (7) with plasmid pDJ252; the presence of the ste2-T326 allele was confirmed by Southern blot analysis. Strains DJ900-B and DJ903-C, both of which contain the $m f \alpha 1:: U R A 3$ allele, were constructed by transforming strains DJ211-5-3 and DJ903-A-1, respectively, with the EcoRI-SalI fragment from plasmid pBH3 (36); PCR analysis was used to confirm the presence of the $m f \alpha 1:: U R A 3$ allele.

Antisera and reagents. Rabbit polyclonal antisera used in immunoblotting procedures were specific for the amino-terminal or the carboxy-terminal portion of the $\alpha$-factor receptor (34); an integral membrane subunit of the vacuolar ATPase, Vph1 (38); a marker of the endoplasmic reticulum, Kar2 (53); the Golgi apparatus lumenal guanosine diphosphatase (GDPase) (1); or the cytosolic marker phosphoglycerate kinase. Mouse monoclonal antibodies C56 (2) were shown to be specific for the plasma membrane ATPase, Pma1, since they could specifically bind a Pma1- $\beta$-lactamase fusion protein (obtained from D. J. Tipper, University of Massachusetts, Worcester). Peroxidase-conjugated secondary antibodies, goat anti-mouse and goat anti-rabbit, were from Kirkegaard and Perry Laboratories, Inc., Gaithersburg, Md. Renografin-76 (76\% Renografin) is a product of Squibb Diagnostics, New Brunswick, N.J. Synthetic $\alpha$-factor was purchased from Sigma Chemical Co., St. Louis, Mo. ${ }^{35}$ S-labelled $\alpha$-factor (approximately $50 \mathrm{Ci} / \mathrm{mmol}$ ) was prepared by culturing strain FY70 (MAT $\alpha$ leu2) containing plasmid pDA6300 (5) in low-sulfate minimal medium with carrier-free $\left[{ }^{35} \mathrm{~S}\right]$ sulfuric acid, and subsequent Bio-Rex 70 chromatography (16) of the resulting culture supernatant.

Membrane fractionation. Cells were cultured overnight at $30^{\circ} \mathrm{C}$ in YM-1 medium (26) to $10^{7}$ cells per ml. Cycloheximide was added to $10 \mu \mathrm{g} / \mathrm{ml}$. After $5 \mathrm{~min}, \alpha$-factor was added to $10^{-8} \mathrm{M}$. At the times indicated, samples containing $5 \times 10^{8}$ cells were removed to prechilled flasks and poisoned by adding $\mathrm{NaN}_{3}$ and $\mathrm{KF}$ to $10 \mathrm{mM}$. Cells were collected by centrifugation, washed with $10 \mathrm{ml}$ of ice-cold sorbitol buffer $(50 \mathrm{mM}$ Tris [pH 7.6], $0.8 \mathrm{M}$ sorbitol, $10 \mathrm{mM} \mathrm{NaN}_{3}, 10 \mathrm{mM} \mathrm{KF}$ ), washed twice with $1 \mathrm{ml}$ of sorbitol buffer, once with $1 \mathrm{ml}$ of sorbitol buffer containing $100 \mu \mathrm{g}$ of phenylmethylsulfonyl fluoride (PMSF) and $2 \mu \mathrm{g}$ of pepstatin A and once with $1 \mathrm{ml}$ of TE (50
$\mathrm{mM}$ Tris [pH 7.5], $1 \mathrm{mM}$ EDTA) containing the same protease inhibitors. The cells were suspended in $0.5 \mathrm{ml}$ of TE containing protease inhibitors and then lysed by mechanical disruption with glass beads. Unbroken cells were removed from the lysate by centrifugation for $5 \mathrm{~min}$ at $330 \times \mathrm{g}$ in a 1.5 -ml microcentrifuge tube in a Sorvall SS-34 rotor. Of the supernatant, $0.5 \mathrm{ml}$ was combined with $0.5 \mathrm{ml}$ of Renografin-76 and placed in the bottom of a centrifuge tube. Flotation gradients were prepared by successively layering $1 \mathrm{ml}$ of $34,30,26$, and $22 \%$ Renografin solutions that had been prepared by diluting Renografin-76 with TE. The gradients were centrifuged in an SW50.1 rotor at $150,000 \times g$ for $20 \mathrm{~h}$ at $4^{\circ} \mathrm{C}$. Fractions $(350 \mu \mathrm{l})$ were collected from the top of each gradient. Samples were diluted 1:3 with sample buffer ( $1 \mathrm{~g}$ of urea dissolved in $1 \mathrm{ml}$ of $17.5 \mathrm{mM}$ Tris- $\mathrm{HCl}[\mathrm{pH} 6.8]$ containing $1.75 \%$ sodium dodecyl sulfate [SDS], $1 \% \beta$-mercaptoethanol, bromophenol blue), heated at $37^{\circ} \mathrm{C}$ for $10 \mathrm{~min}$, and loaded on $10 \%$ polyacrylamide gels for SDS electrophoretic analysis (37). Proteins were transferred to an Immobilon membrane (Millipore Corp, Bedford, Mass.). The membrane was probed with antiserum, and the immune complexes were detected by using the ECL chemiluminescence detection system (Amersham Life Science, Arlington Heights, Ill.). The resulting signal was quantified by using a model SLR-1D/2D Zeineh soft laser scanning densitometer. The density of the fractions was estimated from the refractive index (9).

Determination of receptor half-life. Strains DJ211-5-3 and DJ900-A were grown to mid-log phase and treated with cycloheximide and pheromone (as indicated), and lysates were prepared as for membrane fractionation. After the $330 \times g$ centrifugation step, the protein content of the supernatant was determined by the bicinchoninic acid assay (Pierce, Rockford, Ill.). Samples were diluted to $0.2 \mathrm{mg}$ of protein per $\mathrm{ml}$ with sample buffer, heated at $37^{\circ} \mathrm{C}$ for $10 \mathrm{~min}$, and analyzed by the electrophoretic and immunoblotting methods detailed above.

Protease sensitivity assays. Cells were grown to $10^{7}$ cells per $\mathrm{ml}$ in YM-1 medium at $30^{\circ} \mathrm{C}$. When present, cycloheximide was added to $10 \mu \mathrm{g} / \mathrm{ml}$. The culture was divided into seven $20-\mathrm{ml}$ cultures. $\alpha$-Factor $\left(10^{-8} \mathrm{M}\right.$ final concentration) was added to the cultures at staggered intervals so as to give different durations of $\alpha$-factor exposure and identical durations (20 $\mathrm{min}$ ) of cycloheximide exposure. After pheromone treatment, the cultures were chilled rapidly and $\mathrm{NaN}_{3}$ and $\mathrm{KF}$ were added to $10 \mathrm{mM}$. The cells were collected by centrifugation, washed with $10 \mathrm{ml}$ of sorbitol buffer, and suspended in $1 \mathrm{ml}$ of sorbitol buffer. Each sample was divided into two $500-\mu$ l aliquots. After centrifugation, one cell pellet was suspended in $150 \mu \mathrm{l}$ of sorbitol buffer and the other was suspended in $150 \mu \mathrm{l}$ of sorbitol buffer containing $750 \mu \mathrm{g}$ of chymotrypsin $\mathrm{A}_{4}$ (Boehringer Mannheim, Indianapolis, Ind.). These suspensions were incubated with agitation at $30^{\circ} \mathrm{C}$ for $16 \mathrm{~h}$. Proteolysis was stopped by adding PMSF and $N$-tosyl-L-phenylalanine chloromethyl ketone (TPCK) to $100 \mu \mathrm{g} / \mathrm{ml}$. The cells were collected, washed three times with sorbitol buffer containing PMSF and TPCK, and then suspended in $150 \mu \mathrm{l}$ of sample buffer lacking $\beta$-mercaptoethanol and bromophenol blue and lysed by mechanical disruption with glass beads. Lysates were transferred to fresh tubes and heated at $37^{\circ} \mathrm{C}$ for $10 \mathrm{~min}$, and particulate matter was removed by centrifugation. The protein concentration of the cleared lysates was determined with bicinchoninic acid method and adjusted to $1 \mathrm{mg}$ of protein per $\mathrm{ml}$ with sample buffer (containing $\beta$-mercaptoethanol) and then heated to $37^{\circ} \mathrm{C}$ for $10 \mathrm{~min}$. The proteins were resolved electrophoretically and analyzed by immunoblotting as for membrane fractionation.

Isolation of the ste2-L236H mutant. Plasmid pJBK008 (34) 
containing the STE2 gene was subjected to hydroxylamine mutagenesis (50) and used for the transformation of strain DJ213-7-3. A total of 800 isolates were screened for growth on minimal medium containing $2 \times 10^{-8} \mathrm{M} \alpha$-factor. The 65 $\alpha$-factor-resistant isolates were tested for pheromone-binding activity (30). Only one mutant retained the ability to bind pheromone to the same extent as wild-type cells. The site of the mutation was identified by subcloning various restriction fragments into an otherwise wild-type copy of the STE2 gene contained in plasmid pDJ251. The 274-bp AatII-ClaI fragment that conferred the mutant phenotype was sequenced by using the Sequenase kit (United States Biochemicals, Cleveland, Ohio) and a double-stranded template. Two mutations were found-a G-to-A transition at position 615 and a T-to-A transversion at position 706. The Altered Sites in vitro $\mathrm{Mu}-$ tagenesis System (Promega, Madison, Wis.) was used to create a single T-to-A mutation at position 706 in the STE2 gene. The presence of the mutation was confirmed by DNA sequencing, and the AatII-ClaI fragment was subcloned into plasmid pDJ251. Two-step gene replacement was used to replace the chromosomal copy of STE2 in strain DJ211-5-3 with the mutant gene, creating strain DJ901-A-1. The presence of the mutant allele, which carries a unique $N$ coI restriction site, was confirmed by PCR analysis followed by restriction digestion. Mutant cells containing the single-base-pair substitution (designated ste2- $L 236 \mathrm{H}$ ) exhibited a pheromone response phenotype that was indistinguishable from that of the original isolate.

Pheromone response assays. $\alpha$-Factor halo assays were conducted by moistening sterile filter disks $(0.64-\mathrm{cm}$ diameter $)$ with $20 \mu$ l of various dilutions of $\alpha$-factor $\left(1 \times 10^{-6}\right.$ to $5 \times$ $\left.10^{-5} \mathrm{M}\right)$. The disks were then placed onto yeast extractpeptone-dextrose YEPD solid medium that had been spread with $5 \times 10^{6}$ cells of the strain to be tested. The size and clarity of the zones of growth inhibition (haloes) were noted after 16, 24 , and $48 \mathrm{~h}$ at $30^{\circ} \mathrm{C}$, and the diameters of the zones were measured after $48 \mathrm{~h}$. Agglutination was assayed by the method of Hartwell (27). The time course and dose response for arrest of cell division in the presence of pheromone was determined by the method of Moore (40). The strains used in this work were bar1 mutants defective for $\alpha$-factor destruction, which obviated the need to work at low cell concentrations (30). Cultures of strain DJ211-5-3 (MATa bar1 STE2) and strain DJ901-A-1 (MATa barl ste2- $L 236 H)$ growing exponentially in YM-1 medium at $30^{\circ} \mathrm{C}$ were diluted to $5 \times 10^{5}$ cells per ml, and $\alpha$-factor was added to between $5 \times 10^{-10}$ and $1 \times 10^{-8} \mathrm{M}$. Samples were removed periodically, fixed with formaldehyde $(3.7 \%)$, and sonicated lightly to disperse cell clumps. At least 200 cells from each time point were examined by phasecontrast microscopy, and the number of budded and unbudded cells was noted. The untreated control cultures gave roughly $40 \%$ unbudded cells, whereas maximally induced Ste ${ }^{+}$cultures reached unbudded levels of nearly $100 \%$.

\section{RESULTS}

Previous studies have used indirect techniques to monitor the ligand-induced movement of $\alpha$-factor receptors from the cell surface to internal compartments of the cell. When a cells are exposed to $\alpha$-factor, the pheromone-binding sites disappear from the cell surface in a time- and energy-dependent manner with a concomitant internalization of the ligand (30). Furthermore, $\alpha$-factor receptors are periodically exposed to internal compartments, since the basal rate of receptor turnover is dependent on vacuolar proteases (19). In this study, we have used antibodies to monitor directly the movement and degradation of receptor protein. We provide three lines of evidence for ligand-induced endocytosis of $\alpha$-factor receptors. Membrane fractionation experiments demonstrated that receptors exit the plasma membrane and appear in membranes of lighter buoyant density. Protease sensitivity assays show a reduction in the susceptibility of receptors to extracellular proteolysis upon pheromone addition. The destination of the endocytosed receptors was inferred by comparing the half-lives of the receptors in strains containing or lacking vacuolar proteases.

Membrane fractionation. Centrifugation in Renografin density gradients was used to resolve the plasma membrane from the other membranes of the cell. Previous workers (60) have shown that the major plasma membrane species from $S$. cerevisiae bands at a buoyant density of $1.17 \mathrm{~g} / \mathrm{ml}$ in Renografin gradients. We found that membranes carrying the plasma membrane ATPase band at a similar density of $1.18 \mathrm{~g} / \mathrm{ml}$ and are clearly resolved from membranes containing a vacuolar ATPase subunit, Vph1 (38), which were distributed from a buoyant density of 1.09 to $1.15 \mathrm{~g} / \mathrm{ml}$ (Fig. 1A). Under the conditions used, markers for the endoplasmic reticulum (Kar2) and the Golgi apparatus (GDPase) were also separated from the plasma membrane marker, but they were not resolved from the vacuolar membrane marker (data not shown). Figure 1B shows the buoyant density profiles obtained for the membranes that contain the $\alpha$-factor receptor after the cells had been exposed to $\alpha$-factor for various periods of time. A growing culture of a cells was treated with cycloheximide to block new protein synthesis, and a saturating concentration of $\alpha$-factor was added at time zero. As expected for a cell surface protein, essentially all of the receptor was initially found in a peak corresponding to the density of the plasma membrane. As time progressed, the receptor protein gradually disappeared from these fractions and accumulated in fractions of lighter buoyant density that coincided with the vacuolar ATPase. By $20 \mathrm{~min}$, essentially all of the receptor was in these fractions of lighter density. The positions of the marker proteins within the gradient did not change with the addition of $\alpha$-factor (data not shown). Receptors from control cultures that received cycloheximide and no $\alpha$-factor did not show this shift in density (not shown), indicating that cycloheximide did not cause the redistribution of receptors. Moreover, a similar density shift was obtained with cultures that had been treated with $\alpha$-factor for $12 \mathrm{~min}$ in the absence of cycloheximide (not shown), indicating that for this shorter time course the receptors disappeared from the plasma membrane faster than they were replaced by new synthesis. This result parallels our earlier finding that $\alpha$-factor exposure causes initial down regulation of the cell surface pheromone-binding sites which is followed by a period of reaccumulation (30).

By comparing the relative amounts of receptor protein in the plasma membrane and the vacuolar membrane fractions, we were able to estimate the time required for the transit of receptors between the plasma membrane and the internal compartments of the cell. Figure $1 \mathrm{C}$ shows that with increasing time after pheromone addition an increasing proportion of the receptor left the plasma membrane fractions and appeared in the fractions of lesser density. After an 8-min exposure to $\alpha$-factor, equal amounts of receptor protein were partitioned between the plasma membrane and vacuolar fractions. We were concerned that this period may be an underestimate of the actual transit time, since the degradation of receptors was likely to be more rapid in the vacuolar compartment than in the plasma membrane. However, as described below, the relative degradation rates of the two receptor species does not significantly affect the apparent transit time, since very few receptors, regardless of location, have been degraded during 

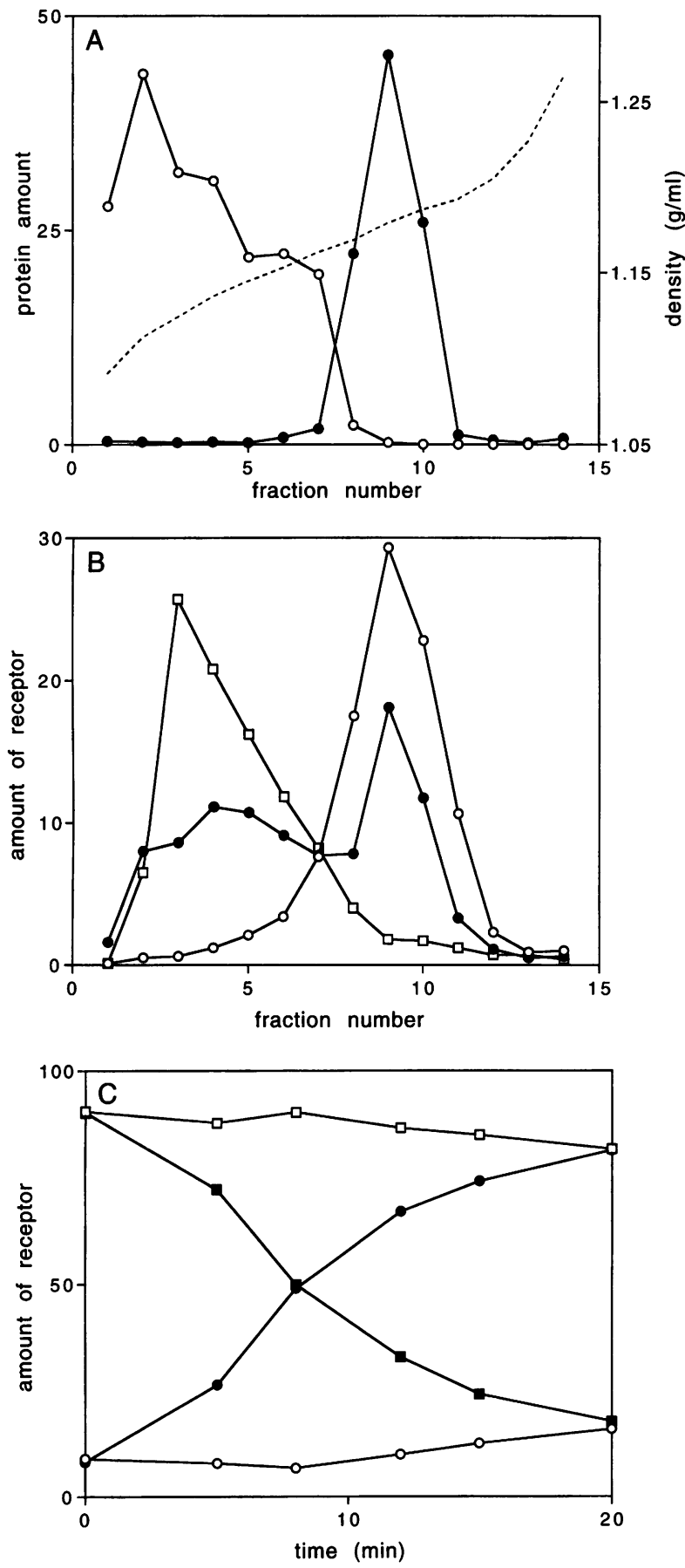

FIG. 1. Membrane fractionation and localization of $\alpha$-factor receptors. (A) Membranes from strain DJ211-5-3 were resolved on Renografin density gradients, and the fractions were assayed for plasma membrane ATPase (O) and an integral membrane subunit of the vacuolar $\mathrm{H}^{+}$ATPase $(O)$. Densities of the fractions are indicated by the dashed line. (B) Strain DJ211-5-3 was treated with cycloheximide $5 \mathrm{~min}$ before the addition of $\alpha$-factor at time zero. At the times indicated, membranes were resolved on Renografin gradients and the fractions were analyzed for $\alpha$-factor receptor by using antibodies directed to the carboxy terminus. The amount of receptor is the percentage found in each fraction. Exposure to $\alpha$-factor was for 0 min $(O), 8 \mathrm{~min}(\mathrm{O})$, and $20 \mathrm{~min}(\square)$. (C) The percentage of receptor molecules found in the plasma membrane peak (fractions 7 to 12) and the percentage of receptors found in the vacuolar peak (fractions 1 to 6) are plotted as a function of the duration of $\alpha$-factor exposure. Receptor found in the plasma membrane peak: $\mathbf{\square}$, culture that

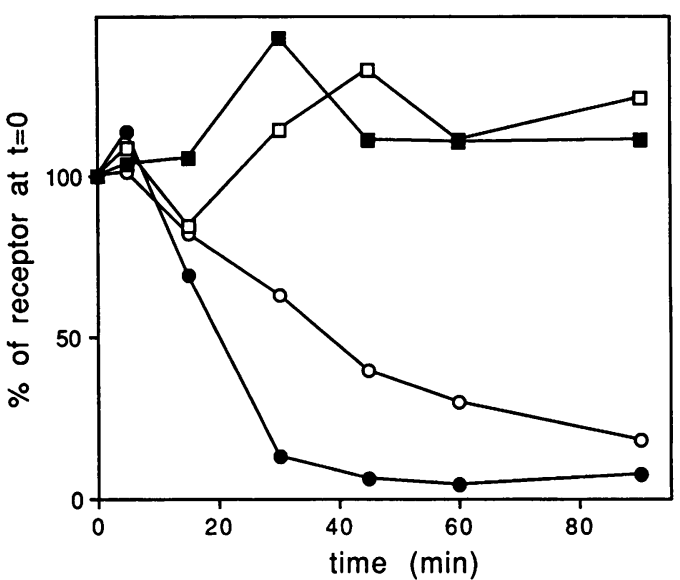

FIG. 2. Turnover of $\alpha$-factor receptors. Strains DJ211-5-3 (PEP4) and DJ900-A (pep4::URA3) were treated with cycloheximide 5 min before the addition of $\alpha$-factor at time zero. Shown is a time course depicting the decay of receptor protein for strain DJ211-5-3 that had been incubated in the presence $(O)$ and in the absence $(O)$ of $\alpha$-factor. No significant decay was observed for strain DJ900-A incubated in the presence $(\square)$ or in the absence $(\square)$ of pheromone.

this 8 -min period (Fig. 2). Hence, $8 \mathrm{~min}$ is an accurate estimate for the median transit time between the plasma membrane and the internal compartments. This value obtained at $30^{\circ} \mathrm{C}$ agrees with our previous determination of $10 \mathrm{~min}$ for the half-life of cell-surface $\alpha$-factor binding sites at $34^{\circ} \mathrm{C}(30)$.

Degradation of $\alpha$-factor receptors is dependent on vacuolar proteases. The shift in density of the membranes carrying $\alpha$-factor receptors following pheromone treatment indicates that the receptors exit the plasma membrane. Although these internalized receptors colocalized with a vacuolar marker protein, an unequivocal assignment of the vacuole as the final destination cannot be made by using these data, as other internal cellular membranes also migrate to this position in the Renografin gradients. As a criterion for determining whether the internalized receptors are directed to the vacuole, we asked whether receptor degradation was stimulated by $\alpha$-factor and whether this degradation was dependent on the proteolytic activities that reside in the vacuole. Since the product of the PEP4 gene is required for the processing of vacuolar proteases, vacuoles in pep 4 mutants are almost completely devoid of proteolytic activities (31). Thus, the exposure of a protein to the vacuolar lumen is suggested by differences in its turnover rates in $P E P 4^{+}$and pep4 strains.

Figure 2 shows the effect of $\alpha$-factor on receptor turnover in a wild-type strain that expresses the normal complement of vacuolar proteases and in a pep 4 mutant that lacks the activities of the major vacuolar proteases. Cells were treated with cycloheximide to block new receptor synthesis, and the subsequent decay of receptor protein was monitored. In the $P E P 4^{+}$strain, the half-life of the receptor was approximately $35 \mathrm{~min}$, whereas in a parallel culture that received $\alpha$-factor, the half-life was reduced to $20 \mathrm{~min}$. In contrast, when the same measurements were made with an isogenic pep 4 mutant, we found that the receptors were stable over the entire length of the 90-min time course, regardless of $\alpha$-factor treatment. Davis et al. (19) have reported a similar PEP4 dependence on the

received $\alpha$-factor; $\square$, untreated control. Receptor found in the vacuolar peak: 0 , culture that received $\alpha$-factor; $\bigcirc$, untreated control. 


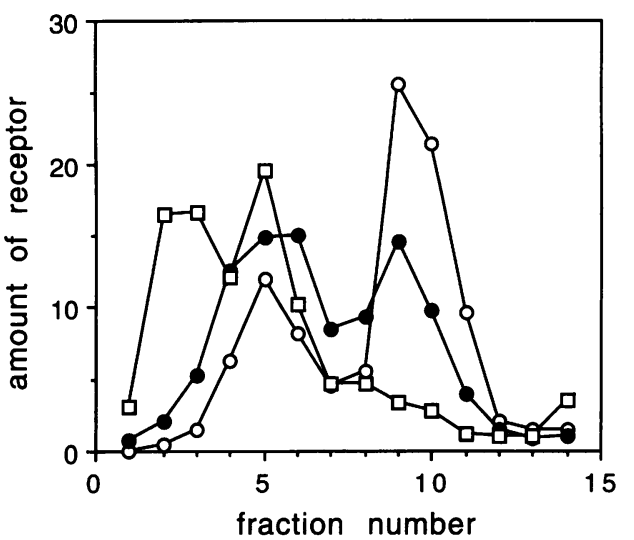

FIG. 3. Membrane fractionation and localization of $\alpha$-factor receptors in strain DJ900-A (pep4::URA3). The culture was treated with cycloheximide $5 \mathrm{~min}$ before the addition of $\alpha$-factor at time zero. After $0 \mathrm{~min}(\bigcirc), 8 \mathrm{~min}(\bigcirc)$, and $20 \mathrm{~min}(\square)$ of $\alpha$-factor exposure, the membranes were resolved by Renografin density gradient centrifugation as for Fig. 1B, and the fractions were assayed for $\alpha$-factor receptor protein by using antibodies directed to its carboxy-terminal domain.

turnover rate of the $\alpha$-factor receptor in the absence of pheromone. Our results indicate that $\alpha$-factor stimulates the movement of the receptors to the vacuole, where they are degraded in a PEP4-dependent manner. The degradation of the receptors in the absence of pheromone presumably reflects basal protein turnover, which also occurs in the vacuole. Since the accumulation of receptors in the vacuole was not detectable in the absence of $\alpha$-factor (Fig. 1B), the rate-determining step in receptor turnover is apparently delivery to the vacuole rather than degradation of material that has reached the vacuole. In contrast, since a vacuolar pool of receptors accumulates in the presence of $\alpha$-factor, it appears that the faster internalization rate causes degradation in the vacuole to become rate limiting.

Renografin density gradient centrifugation was used to ensure that the stability of the receptors in the pep 4 mutant was not a consequence of failure to exit the plasma membrane. Figure 3 shows that the majority of receptors are present in the plasma membrane fractions in the absence of $\alpha$-factor and that they appear in the vacuolar fractions after the cells have been exposed to $\alpha$-factor. However, a number of differences can be noted in comparing the gradient profile of the pep4 mutant (Fig. 3) with that of the PEP4 ${ }^{+}$strain (Fig. 1B), even though the localization of the marker proteins is not affected by the pep4 mutation (data not shown). Before $\alpha$-factor treatment, a significant proportion of receptor in the pep4 strain was found in fraction 5, a fraction that contains a portion of the vacuolar marker protein (Fig. 1A). We expected some of the receptor to be initially present in the vacuole in the pep 4 mutant, since the receptors that would have migrated to the vacuole as part of the basal receptor turnover would fail to be degraded in this protease-deficient strain. With increasing time after pheromone addition, the receptor left the plasma membrane peak and shifted to fraction 5 and eventually appeared in fraction 2 , illustrating that the receptors in the pep 4 mutant are capable of exiting the plasma membrane. Whether the material in fraction 5 represents a transport intermediate is unclear, since the vacuolar marker protein $\mathrm{Vph} 1$ is found in a broad peak spanning fractions 1 through 7 (Fig. 1A).

Proteolytic cleavage of cell surface receptors. Further evidence supporting the exit of receptors from the plasma mem- brane in response to $\alpha$-factor was obtained by examining the susceptibility of receptors to extracellular proteases. Under the appropriate conditions, the receptors present at the cell surface are expected to be cleaved by exogenously added protease, while the internal receptors remain protected from proteolysis. Optimal assay conditions were sought by exposing intact cells to a number of different proteases under a variety of digestion conditions. Following electrophoretic analysis of whole-cell extracts, antibodies specific for the carboxy-terminal cytoplasmic domain of the receptor were used to detect intact receptors as well as the proteolytic fragments generated by cleavages in the exposed amino-terminal extension and in the extracellular loops of the receptor. Antibodies to phosphoglycerate kinase (PGK) were used to monitor proteolysis of cytoplasmic proteins. Trypsin digestion proved to be unsuitable, as it gave insufficient cleavage of the receptor whereas pronase and proteinase $\mathrm{K}$, even though they cleaved the receptor efficiently, were also unsuitable since they resulted in nonspecific degradation of other cellular proteins as evidenced by the proteolysis of PGK and by a general loss of highmolecular-weight proteins on Coomassie blue-stained gels (data not shown). Chymotrypsin was chosen for our assay as it gave nearly complete cleavage of the receptor without affecting the levels of intact PGK (Fig. 4) or bulk protein (not shown). The cycloheximide that was added to the cultures to prevent new protein synthesis, however, appeared to inhibit the action of chymotrypsin, since a slightly reduced extent of receptor cleavage was observed for the cultures that had been treated with cycloheximide (compare lane 8 in Fig. 4A with lane 8 in Fig. 4B). Moreover, cultures treated with cycloheximide for a longer duration showed a greater reduction in chymotrypsin susceptibility (not shown). For this reason, the results depicted in Fig. 4A were obtained with multiple identical cultures in which the addition of $\alpha$-factor was staggered so that the period of cycloheximide exposure would remain constant for each of the time points.

As depicted in Fig. 4, pheromone receptors showed a reduced susceptibility to proteolytic cleavage when the cultures were exposed to $\alpha$-factor. Cells of the pep 4 strain that had been exposed to $\alpha$-factor for various lengths of time were poisoned with $\mathrm{NaN}_{3}$ and $\mathrm{KF}$ to prevent further internalization of the receptor and then treated with chymotrypsin to cleave the receptors at the cell surface. The intact receptor species were defined as the forms that were present in controls that did not receive chymotrypsin-full-length receptors are known to be glycosylated and give multiple electrophoretic bands $(5,34)$. The proteolyzed species were defined as the forms that were present only in the reaction mixtures that contained chymotrypsin. Nearly all of the receptors were susceptible to chymotrypsin at early times after $\alpha$-factor addition, since the majority of the immunoreactive material was recovered as proteolytic fragments ranging in size from 20 to $30 \mathrm{kDa}$, corresponding to cleavage in the extracellular loops. With increasing duration of $\alpha$-factor exposure, recovery of the proteolytic fragments decreased as recovery of the intact receptor molecules increased, consistent with the receptors leaving the cell surface and moving to an internal compartment where they were protected from proteolysis. By $20 \mathrm{~min}$, essentially all of the receptor protein was recovered as the intact, protected species.

The rate at which the cell surface receptors were protected from proteolysis was the same for the cells that had been cultured in the presence (Fig. 4A) or in the absence (Fig. 4B) of cycloheximide. Thus, it appears that the loss of protease sensitivity is not a result of cycloheximide treatment, nor are the kinetics of acquired resistance to chymotrypsin altered by cycloheximide treatment. Moreover, the rate of appearance of 
A.

$\begin{array}{lllllllllllllll}\text { time (min) } & 0 & 2 & 5 & 8 & 12 & 15 & 20 & 0 & 2 & 5 & 8 & 12 & 15 & 20\end{array}$

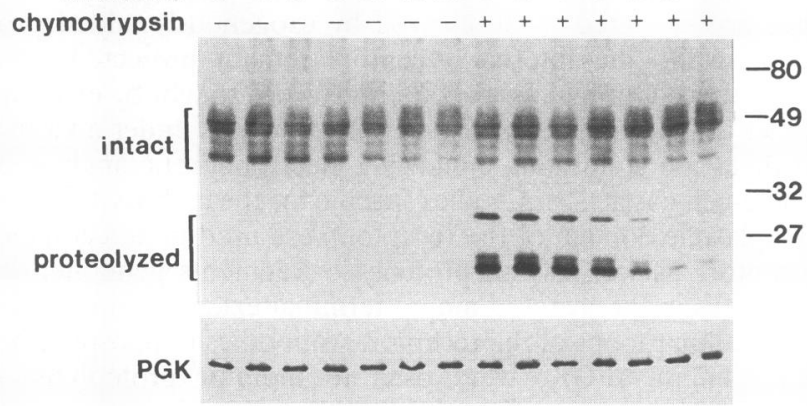

B.

$\begin{array}{lllllllllllllll}\text { time(min) } & 0 & 2 & 5 & 8 & 12 & 15 & 20 & 0 & 2 & 5 & 8 & 12 & 15 & 20\end{array}$

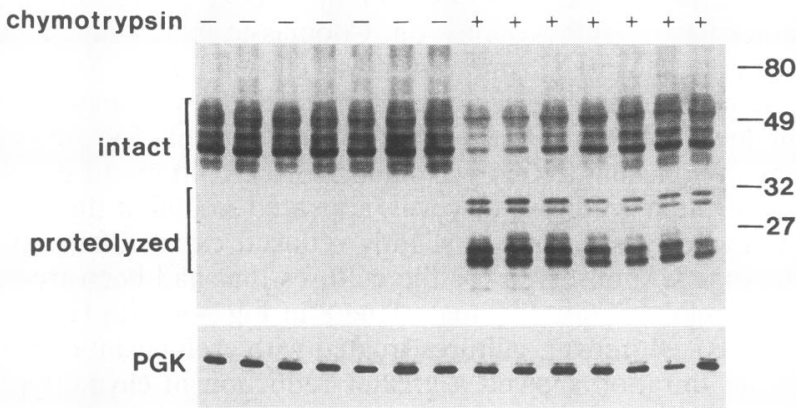

FIG. 4. Sensitivity of $\alpha$-factor receptors to exogenous protease. Strain DJ900-A (pep4::URA3) was exposed to $\alpha$-factor for the duration indicated in the presence (A) or absence (B) of cycloheximide. Cells were poisoned with $\mathrm{NaN}_{3}$ and $\mathrm{KF}$ and then subjected to chymotrypsin digestion $(+)$ or mock protease treatment $(-)$. Proteolytic products of the receptor were resolved electrophoretically and detected with antibodies directed to the intracellular carboxy-terminal domain. The positions of the intact forms and the proteolyzed forms of the receptor are indicated at the left and molecular mass markers (in kilodaltons) are shown at the right of each panel. To monitor nonspecific proteolysis of cytoplasmic proteins, the immunoblots were reprobed with antibodies directed to the cytoplasmic protein PGK (bottom of each panel).

chymotrypsin-resistant receptors mirrors the rate at which receptors were removed from the plasma membrane as determined by Renografin density gradient centrifugation (Fig. 1C). However, minor differences between the cycloheximidetreated and untreated cultures were observed. As mentioned above, cycloheximide reduced the efficiency of receptor cleavage that was apparent in the samples from shorter periods of $\alpha$-factor exposure, since more of the receptor remained intact in the presence of cycloheximide even though the majority of these receptors were at the cell surface (Fig. 3). In the absence of cycloheximide, the persistence of some chymotrysin-sensitive receptors after the longest $\alpha$-factor exposures was anticipated because of the continued synthesis of new receptors in the absence of cycloheximide. For the cycloheximide-treated cultures, $\alpha$-factor exposure also reduced the recovery of receptors in the samples that did not receive chymotrypsin during the control incubation (Fig. 4A, first seven lanes). This twofold loss is likely to be a consequence of slow degradation of intracellular receptors by the endogenous proteolytic activities present even in a pep4 strain, since there was no loss of

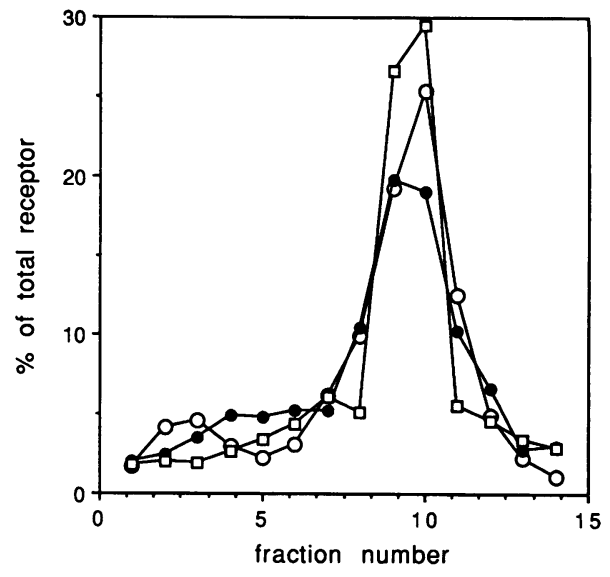

FIG. 5. Membrane fractionation and localization of truncated receptors during $\alpha$-factor treatment. Strain DJ903-C (MATa ste2-T326 $m f \alpha 1:: U R A 3)$ was treated with cycloheximide $5 \mathrm{~min}$ before the addition of $\alpha$-factor at time zero. After $0 \mathrm{~min}(\bigcirc), 8 \mathrm{~min}(\Theta)$, and $20 \mathrm{~min}$ ( $\square$ ) of $\alpha$-factor exposure, the membranes were resolved by Renografin density gradient centrifugation as for Fig. 1B, and the fractions were assayed for $\alpha$-factor receptor protein by using antibodies directed to its amino-terminal domain

receptors in the pep4 strain when this second incubation was omitted (Fig. 2). In the absence of cycloheximide, this reduction in receptor level was probably offset by the increased rate of receptor synthesis that is induced by $\alpha$-factor $(25,30)$.

Internalization defects of truncated $\alpha$-factor receptors. The carboxy-terminal cytoplasmic domains of many cell surface receptors have been shown to contain sequences necessary for receptor internalization (59). The carboxy-terminal cytoplasmic domain of the $\alpha$-factor receptor appears to consist of 133 amino acids. Truncation mutants that remove part or all of this domain lead to $\alpha$-factor hypersensitivity and a failure to recover from $\alpha$-factor exposure $(34,47)$. The role of this domain in receptor down regulation and pheromone internalization has been explored in several laboratories $(34,47,49)$. To look directly at the ability of truncated receptors to leave the plasma membrane in response to pheromone, we employed our membrane fractionation and chymotrypsin susceptibility assays. The truncation allele ste2-T326 was analyzed in this study for the purpose of clarifying conflicting reports in the literature concerning the capacity of these mutant receptors to undergo ligand-stimulated internalization $(34,49)$. Cells carrying $M A T$ a bar1 ste2-T326 are supersensitive to pheromone because of the receptor truncation (34) and because of the barl mutation, which blocks $\alpha$-factor degradation $(13,56)$. Thus, many of these cells in culture are large and distended, presumably because they respond to the low level of $\alpha$-factor produced by the a cells that have switched mating type. We found that the MATa bar1 ste2-T326 mfal::URA3 strain used in our receptor internalization assays did not exhibit this phenotype, consistent with the $M F \alpha 1$ gene being the major source of $\alpha$-factor in $\alpha$ cells (36).

The MATa barl ste2-T326 $m f \alpha 1:: U R A 3$ strain was subjected to the Renografin density gradient centrifugation analysis described in the legend to Fig. 1. As shown in Fig. 5, the truncated receptors failed to leave the plasma membrane peak, even after a 20 -min exposure to pheromone. The presence of the $m f \alpha 1:: U R A 3$ allele did not affect the endocytosis of wildtype receptors or the position of the marker proteins within the gradient (data not shown). As further evidence for the failure 
of the truncated receptors to leave the plasma membrane in response to $\alpha$-factor, we looked at the susceptibility of the truncated receptors to chymotrypsin cleavage (not shown). In this test, cells were exposed to pheromone and then treated with chymotrypsin as described in the legend to Fig. 4, except that antiserum directed against the amino-terminal domain of the receptor was used for the Western blot (immunoblot) analysis. We found that none of the receptors was protected from chymotrypsin degradation even after a 20 -min exposure to $\alpha$-factor; however, the use of the amino terminus-specific antibodies precluded the detection of the proteolytic fragments generated by cleavage of cell surface receptors.

These data support the view that the truncated receptors fail to exit the plasma membrane in response to pheromone. This is consistent with the inabilities of these truncated receptors to internalize pheromone and to undergo down regulation (49). The ability of the truncated receptor sites to undergo $\alpha$-factorinduced down regulation in the earlier reports (34) was apparently due to blockage of the cell surface binding sites by the initial $\alpha$-factor exposure, since longer washing periods following $\alpha$-factor treatment revealed that the receptor sites were not lost from the cell surface (49, and unpublished data). Although the truncated receptors show a normal affinity for $\alpha$-factor $(34,47)$, the rates of association and dissociation of the ligand are reduced significantly (46, and unpublished data). These observations underscore the importance of using a direct assay for the internalization of receptor protein, since irreversible association of $\alpha$-factor with its cell surface receptor sites can result in the down regulation of cell surface receptor sites and apparent $\alpha$-factor internalization.

$\alpha$-Factor-induced internalization of receptors defective for pheromone response. The results of the preceding section and other published reports $(47,49)$ suggest that the intracellular factors controlling receptor internalization recognize structural features of the receptor contained in its carboxy-terminal cytoplasmic domain. Apparently, different structural features are recognized during the signal transduction events that lead to the arrest of cell division and the transcriptional induction of pheromone-responsive genes. In order to determine whether the structural features that specify signal transduction also participate in receptor internalization, we wished to examine the internalization properties of receptor mutants that block pheromone-induced transcription and cell division arrest. By using in vitro mutagenesis of the entire STE2 gene, we obtained mutation ste2- $2236 \mathrm{H}$, which encoded receptors that retained normal pheromone-binding activity and yet failed to arrest cell division in response to $\alpha$-factor. This substitution of histidine for leucine in the third cytoplasmic loop of the receptor was also isolated by Weiner et al. (61) after exhaustive PCR mutagenesis of the sequence encoding the third intracellular loop. Weiner et al. (61) found that this mutant receptor is partially defective for $G$ protein coupling in that $\alpha$-factor affinity is only marginally influenced by the binding of nucleotides to the $G$ protein. The mutant cells require six times more $\alpha$-factor to give comparable transcriptional induction of a pheromone-responsive gene (FUS1-lacZ) and four times more $\alpha$-factor to give a comparable zone of growth inhibition in an $\alpha$-factor halo assay. We found a comparable fivefold reduction in $\alpha$-factor sensitivity for the mutant in the halo assay, but the ability of the mutant to induce the synthesis of cell surface agglutinins was reduced by 100 -fold (50\% effective concentration $=2 \times 10^{-8} \mathrm{M} \alpha$-factor for the mutant versus 2 $\times 10^{-10} \mathrm{M}$ for the wild-type control). As shown in Fig. 6, the mutant cells arrest division and recover from the effects of $1 \times$ $10^{-7} \mathrm{M} \alpha$-factor in a manner that is indistinguishable from wild-type cells that had been exposed to $2.5 \times 10^{-9} \mathrm{M}$; hence,
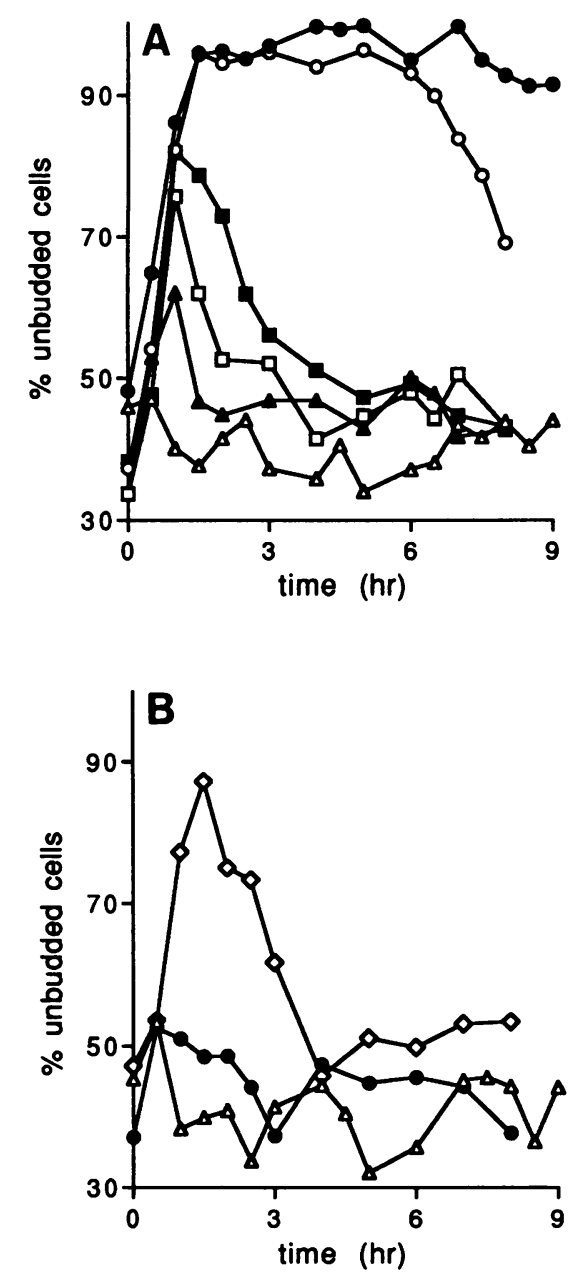

FIG. 6. Pheromone response of the ste2-L236H signalling-defective mutant. Strain DJ211-5-3 (STE2) and strain DJ901-A-1 (ste2-L236H) were cultured with various concentrations of $\alpha$-factor. The percentage of unbudded cells in these cultures is plotted as a function of the duration of $\alpha$-factor exposure. (A) Strain DJ211-5-3 (STE2) received 1 $\times 10^{-8} \mathrm{M}(\mathbf{O}), 5 \times 10^{-9} \mathrm{M}(\mathrm{O}), 2.5 \times 10^{-9} \mathrm{M}(\mathbf{\square}), 1 \times 10^{-9} \mathrm{M}(\square)$, or $5 \times 10^{-10} \mathrm{M} \alpha$-factor $(\boldsymbol{\Delta})$ or no pheromone $(\triangle)$. (B) Strain DJ901-A-1 (ste2-L236H) received $10^{-7} \mathrm{M}(\diamond)$ or $10^{-8} \mathrm{M}(\boldsymbol{\Theta}) \alpha$-factor or no pheromone $(\triangle)$.

this behavior of the mutant also indicates a weaker response to $\alpha$-factor.

The pheromone response defect of the ste2- $2236 \mathrm{H}$ mutant does not block its ability to internalize $\alpha$-factor (61). We wished to determine directly whether the ste2- $L 236 \mathrm{H}$ mutant blocks the ability of $\alpha$-factor receptors to exit the plasma membrane and move to an internal compartment. The Renografin density gradient fractionation technique was used to examine movement of the ste2- $\mathrm{L} 236 \mathrm{H}$ mutant receptors in response to $\alpha$-factor. With increasing duration of $\alpha$-factor exposure, the mutant receptors shifted from the plasma membrane fractions to a position of lesser buoyant density in the gradient (Fig. 7). A similar shift was observed for the wild-type receptors (Fig. 1B). The rate of this process is also very similar to the wild-type case. Thus, the ste2-L236H mutation, which decreases pheromone responsiveness, has no detectable effect on the internalization of receptors. 


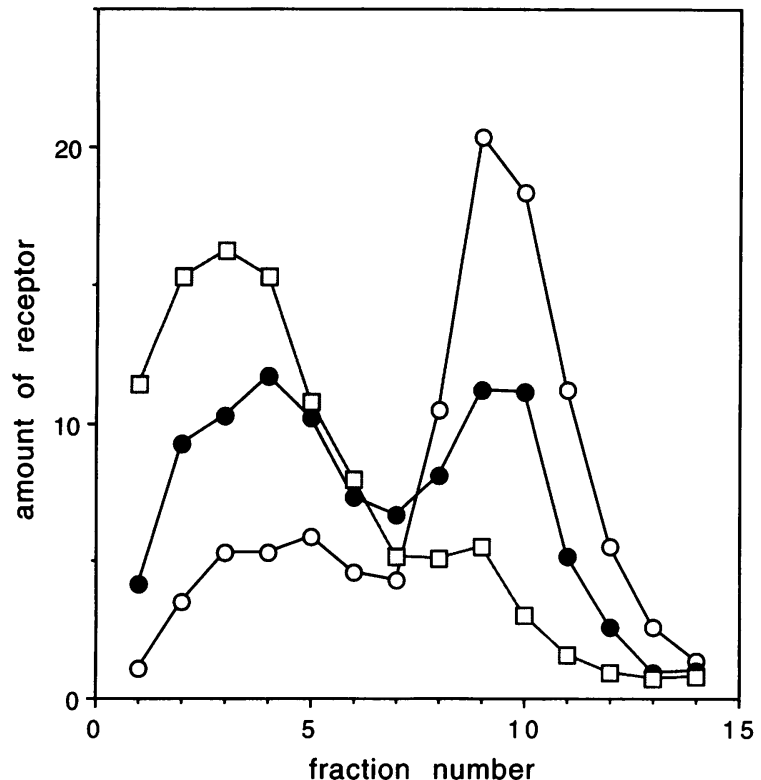

FIG. 7. Membrane fractionation of cells expressing signalling-defective receptors. Strain DJ901-A-1 (ste2-L236H) was treated with cycloheximide and presented with $\alpha$-factor at time zero. After 0 min (O), $8 \mathrm{~min}(O)$, and $20 \mathrm{~min}(\square)$ of $\alpha$-factor exposure, the membranes were resolved by Renografin density gradient centrifugation as for Fig. $1 \mathrm{~B}$, and the fractions were assayed for $\alpha$-factor receptor protein by using antibodies directed to its carboxy-terminal domain.

\section{DISCUSSION}

We report the first direct evidence for ligand-stimulated internalization of the $\alpha$-factor receptor, and we have tested whether specific mutant receptors are internalized in response to ligand. Previous evidence supporting internalization was indirect in that it was based on the down regulation of cell surface binding sites that accompanied pheromone internalization $(14,30)$. Although these results provided preliminary evidence for ligand-mediated endocytosis of the $\alpha$-factor receptor, this interpretation was limited by the possibility that the receptors were inactivated by $\alpha$-factor binding or that $\alpha$-factor bound irreversibly to receptor sites that remained at the cell surface. Indeed, we have found that the down regulation of surface receptor sites observed for truncated forms of the receptor $(34,47)$ appears to be a consequence of stable binding of $\alpha$-factor to the receptor sites rather than ligand-mediated endocytosis. We report methods that directly measure the ligand-induced removal of the $\alpha$-factor receptor from the plasma membrane. The membrane fractionation studies showed that the receptors exited the plasma membrane when the cells had been exposed to pheromone and that these receptors could be recovered in fractions of lighter buoyant density containing vacuolar membrane proteins. Moreover, $\alpha$-factor exposure led to a sequestered form of the receptor that was no longer susceptible to cleavage by chymotrypsin. Davis et al. (19) have recently reported that the basal turnover of $\alpha$-factor receptors is dependent on the activity of vacuolar proteases. We find that receptor turnover is stimulated by $\alpha$-factor exposure and that the more rapid turnover rate is also dependent on vacuolar protease activity. Thus, it appears that the final destination for both occupied and unoccupied receptors is the vacuole. Whether basal and ligand-induced endocytoses follow the same pathway from the plasma membrane to the vacuole is not known.
The kinetics at which $\alpha$-factor receptors exited the plasma membrane allowed us to estimate the time required for the receptors to be translocated from the plasma membrane to the internal compartments of the cell. For cells that had been growing in the absence of $\alpha$-factor, all of the receptors were found in the plasma membrane fractions and were susceptible to chymotrypsin cleavage in whole cells. We were able to follow the fate of these receptors after $\alpha$-factor addition, since the synthesis of new receptors had been blocked with cycloheximide. After $8 \mathrm{~min}$, half of the receptors had left the cell surface. Since the half-life of total receptor protein was $20 \mathrm{~min}$ in the presence of $\alpha$-factor and since receptors accumulated in the vacuolar fractions during this period, we concluded that the clearance of receptors in the presence of $\alpha$-factor was limited by the rate of their degradation in the vacuole. Our inability to detect receptors in vacuolar fractions in the absence of pheromone suggests that the basal rate of turnover is limited by exit from the plasma membrane. Therefore, the presence of pheromone stimulates the removal of the receptors from the plasma membrane, perhaps by altering the conformation of the receptor so that it is more efficiently recognized by the endocytic machinery of the cell. The presence of cycloheximide in these experiments did not appear to affect the initial kinetics of receptor movement, since identical results were obtained for the early time points when cycloheximide was omitted. Previous studies also showed that cycloheximide had no effect on the initial rate at which receptor binding sites disappeared from the cell surface (30).

The characteristics of $\alpha$-factor receptor internalization reported here are similar to those reported by Singer and Riezman for the internalization of $\alpha$-factor pheromone (54). Half of the pheromone is internalized after $4 \mathrm{~min}$ at $30^{\circ} \mathrm{C}(54)$. Singer and Riezman used Nycodenz density gradients to show that pheromone internalized for $20 \mathrm{~min}$ at $15^{\circ} \mathrm{C}$ was resolved into two peaks corresponding to buoyant densities of 1.12 and $1.14 \mathrm{~g} / \mathrm{ml}(54)$. After $20 \mathrm{~min}$ at $30^{\circ} \mathrm{C}$, we found the receptor in a similar range of 1.09 to $1.15 \mathrm{~g} / \mathrm{ml}$ in Renografin gradients. The association of the internalized $\alpha$-factor with two different membrane fractions may represent intermediates in the endocytic pathway such as early and late endosomes (55) or possibly the vacuolar compartment. Whether the pheromone and the receptor remain in a stable complex as they are translocated through the pathway is not known; however, it is clear that both reach the same final destination, as the degradation of the pheromone, as well as the receptor, is dependent on vacuolar proteases (54).

Our findings concerning the internalization of the $\alpha$-factor receptor are similar to recent reports $(19,58)$ concerning a-factor receptor internalization. Turnover of a-factor receptors is dependent on vacuolar proteases (half-life $=20 \mathrm{~min}$ at $30^{\circ} \mathrm{C}$ in the absence of pheromone) (19). In the presence of a-factor, receptors were found to move into a proteaseresistant compartment within $60 \mathrm{~min}$ at $30^{\circ} \mathrm{C}$ (19). Further protease susceptibility studies of the a-factor receptor that were conducted at $37^{\circ} \mathrm{C}$ showed that the half-life for receptor internalization was between 11 and $15 \mathrm{~min}(58)$, a range that is similar to that observed for the $\alpha$-factor receptor at $30^{\circ} \mathrm{C}$. Immunofluorescence studies using cells overexpressing the a-factor receptor provided evidence supporting the movement of receptors from the plasma membrane to the vacuole; however, because the vacuole contained a significant number of receptors before the cells had been exposed to pheromone, it is unclear whether additional receptors were delivered to the vacuole or were simply lost from the cell surface. Davis et al. (19) also reported the isolation of a trans-acting mutation, ren1-1 (allelic to vps2), that affects receptor internalization. 
This mutation also blocks the turnover of both pheromone receptors, thereby suggesting that a common mechanism is used for the endocytosis of both receptors. These authors also found that mutation ren1-1 blocked the ligand-induced as well as the basal turnover of truncated a-factor receptors (19), suggesting that the basal and the ligand-induced endocytic pathways also share common steps. Even though an intracellular compartment is the major site of a-factor receptor accumulation in the ren 1-1 mutant, the overall rate at which receptors are lost from the cell surface is reduced. This raises the possibility that endocytosed receptors recycle from this intermediate compartment to the cell surface (19). Our results with the $\alpha$-factor receptor do not address the issue of receptor recycling. The overall rate at which $\alpha$-factor receptors are lost from the plasma membrane may be a composite of the rates of internalization and recycling.

The endocytic signal carried by cell surface receptors is commonly contained in the cytoplasmic, carboxy-terminal tail. The cytoplasmic tail of the $\alpha$-factor receptor is thought to include residues 298 through 431 of the polypeptide backbone $(8,10,43)$. Conflicting reports regarding the role of this domain in endocytosis have been based on indirect assays that measure the abilities of truncated receptors to promote $\alpha$-factor internalization and to undergo ligand-stimulated down regulation of the cell surface $\alpha$-factor binding sites. Reneke et al. (47) found that truncation at position 296 blocked down regulation, whereas truncation at position 313 resulted in a reduced capacity for down regulation. Konopka et al. (34) found that truncation at position 326 blocked the basal rate at which surface receptor sites were lost but failed to block ligand-stimulated down regulation of the sites. In contrast, Rohrer et al. (49) found that a truncation at this position completely blocked down regulation. Further studies of the dissociation rates for bound $\alpha$-factor conducted under the same assay conditions used in the down regulation assays (30) reveal that the $k_{\text {off }}$ rate is reduced 3-fold for the ste2-T326 mutant (our unpublished results) and 3- to 10-fold for internal deletions of the carboxy-terminal domain (46), even though the $K_{d}$ values are unaffected $(34,47)$. Thus, the standard indirect assays for endocytosis do not reliably measure receptor internalization because they depend on the dissociation of $\alpha$-factor bound to cell surface receptors. The direct assays reported here indicate that receptors truncated at position 326 remain at the plasma membrane after $\alpha$-factor exposure, in agreement with the down regulation and $\alpha$-factor internalization assays of Rohrer et al. (49).

By making point mutations and small internal deletions in the cytoplasmic tail of the $\alpha$-factor receptor, Rohrer et al. (49) determined that the peptide sequence DAKSS spanning residues 335 to 339 is required for pheromone internalization and receptor down regulation. Thus, cellular factors that regulate receptor internalization require, at least in part, this portion of the cytoplasmic tail. Truncated receptors are found in greater numbers on the cell surface $(34,47)$, presumably because of their reduced basal turnover (34). Hence, the endocytic signal or signals found in the carboxy-terminal tail of the $\alpha$-factor receptor appear to control both basal and ligand-induced internalization. The a-factor receptor also appears to carry an internalization signal in its cytoplasmic tail, but this signal is probably required only for basal receptor turnover (19). Deletion of the final 105 amino acid residues of the a-factor receptor (truncation at position 365, leaving a 79-residue cytoplasmic tail) results in receptors that show increased stability in the absence of a-factor but that remain subject to ligand-induced endocytosis. A consensus endocytic sequence, DXKXS, as defined by Rohrer et al. (49), spans residues 397 to
401 and thus is eliminated by truncation at position 365 . In the case of the a-factor receptors, this presumptive endocytic signal is apparently required only for constitutive endocytosis. Perhaps a second endocytic signal, one that is eliminated in the ste2-T326 mutant but not in the ste3-T365 mutant, is required for ligand-induced internalization.

Binding of $\alpha$-factor to its receptor initiates the signal transduction events controlling pheromone response in addition to its role in promoting receptor endocytosis. As a consequence of its association with pheromone, the receptor is likely to assume one or more conformational states that allow intracellular factors to recognize the ligand-occupied state. Two types of information suggest that the factors responsible for receptor internalization differ from the factors controlling signal transduction. First, trans-acting mutations that alter signal transduction do not affect receptor-mediated endocytosis, and other trans-acting mutations that block endocytosis do not affect signal transduction. Second, truncated receptors are specifically defective for endocytosis, whereas amino acid substitutions in the third cytoplasmic loop of the receptor are specifically defective for signal transduction. Transacting mutations in the $E N D 3, E N D 4$, and $R E N 1$ genes block $\alpha$-factor internalization, yet these mutations do not affect mating or signal transduction $(19,45)$. Similarly, mutations in the actin gene $A C T 1$, the clathrin heavy chain gene $C H C 1$, and the gene for the yeast fimbrin homolog, $S A C 6$, lead to defects in pheromone internalization but have little effect on signal transduction $(35,48)$. Furthermore, an intact signal transduction pathway is not required for receptor endocytosis. Mutations in the STE4 gene, encoding the $\beta$ subunit of the heterotrimeric $G$ protein, or in the STE5 gene block signal transduction events but have no effect on the down regulation of the receptor (30, 63 ), whereas mutations in the GPA1 gene, encoding the G protein $\alpha$ subunit, cause constitutive activation of pheromone response without affecting the ability of receptors to undergo down regulation (4). Pheromone receptors expressed from a plasmid under the control of the GAL promoter in diploid cells were competent for endocytosis, even though diploid cells do not have a functional pheromone response pathway $(19,63)$.

To test whether signal transduction plays a role in the endocytosis of the receptor, we examined the capacity of ste2- $L 236 H$ mutant receptors to undergo ligand-induced endocytosis. Weiner et al. (61), who originally identified this mutation, showed that it blocks the ability of the receptor to couple with the $G$ protein in cell-free extracts, that it partially blocks the ability of cells to respond to $\alpha$-factor, and that it does not block $\alpha$-factor internalization as judged by the stable association of $\alpha$-factor with metabolically active cells. Our results show that this coupling-deficient receptor has a reduced capacity to mediate cellular responses to $\alpha$-factor, yet it is able to undergo ligand-induced endocytosis, in agreement with the $\alpha$-factor internalization results of Weiner et al. (61). The weaker $\mathrm{G}$ protein-mediated response observed for this mutant is anticipated from the analysis of hybrid adrenergic receptors in which the third cytoplasmic loop of the receptor was found to specify $G$ protein interaction (22). Taken together, the results with the ste2- $L 236 \mathrm{H}$ mutant and the truncation mutants indicate that different structural features of the receptor specify its interaction with the endocytic and signal transduction pathways.

Although the ste2- $\mathrm{L} 236 \mathrm{H}$ mutant cells show reduced responsiveness to $\alpha$-factor, it is difficult to establish whether this defect reflects a reduced capacity to generate the initial signal or an increased sensitivity to the regulatory processes that dampen the signal. Since the length of time required for cells to recover from $\alpha$-factor is proportional to the $\alpha$-factor con- 
centration used (41), mutant cells that generate a weaker signal are expected to recover more rapidly. $\alpha$-Factor halo assays are often used as a qualitative measure for adaptation, since the cells within the zone of growth inhibition that surrounds a source of $\alpha$-factor eventually grow to fill the zone. Weiner et al. (61) propose that the ste2- $2236 \mathrm{H}$ mutant receptors promote an adaptation pathway, since halo assays of the mutant initially give a clear zone that fills in more rapidly than the wild-type control and since the sst 2 mutation, which blocks adaptation $(12,20)$, also blocks the ability of the ste2- $L 236 \mathrm{H}$ mutant to fill the zone. In contrast, we believe that the transient arrest of cell division of the mutant cells within the zone and the effects of the sst 2 mutation could be simple consequences of a weaker signal in the ste $2-2236 \mathrm{H}$ mutant and the profound sensitivity of sst 2 mutants to weak signals. Moreover, after the 2-day incubation period required for this assay, it is difficult to distinguish the inability to adapt from an inability to survive prolonged $\alpha$-factor exposure. The adaptation phenotype of the ste2- $L 236 \mathrm{H}$ mutant could simply result from the generation of a weaker signal, since our results show the same arrest and recovery profiles for the mutant cells at $10^{-7} \mathrm{M} \alpha$-factor as for the wild-type cells at $2.5 \times 10^{-9} \mathrm{M}$ $\alpha$-factor (Fig. 6). Furthermore, we found zones of $\alpha$-factor inhibition that were turbid and remained turbid throughout the course of observation when halo assays were conducted with the mutant cells. Thus, the reduced pheromone responsiveness of the ste $2-\mathrm{L} 236 \mathrm{H}$ mutant is consistent with the generation of a weaker signal or with an increased ability to adapt to the signal.

In conclusion, we have examined the ability of this responsedefective mutant to internalize the pheromone receptor. Using the direct internalization assays described here, we have shown that cells expressing ste $2-L 236 H$ are competent for receptor endocytosis. This provides further evidence that the signals for receptor internalization and signal transduction are separable at the level of the receptor, suggesting that different domains of the receptor participate in these two functions. Different structural features of the receptor appear to be recognized by the endocytic machinery and the signal transduction apparatus within the cell. The carboxy-terminal cytoplasmic tail is required for the endocytosis of the receptor, while the third cytoplasmic loop plays a role in signal transduction. However, we cannot rule out the possibility that some structural features of the receptor are required for both functions. A more detailed mutational analysis of the receptor is required to further define the functional domains of the receptor.

\section{ACKNOWLEDGMENTS}

We thank James Konopka, Jeremy Thorner, Morris Manolson, John Aris, Elizabeth Jones, Janet Kurjan, and Patricia Berninsone for their generous gifts of antisera and plasmids. We also thank Phyllis Spatrick and Christopher Tipper for technical assistance.

This investigation was supported by Public Health Service research grant GM34719 from the National Institutes of Health. K. A. Schandel was supported by a postdoctoral fellowship from the American Cancer Society (PF-3556).

\section{REFERENCES}

1. Abeijon, C., P. Orlean, P. W. Robbins, and C. B. Hirschberg. 1989. Topography of glycosylation in yeast: characterization of GDP mannose transport and lumenal guanosine diphosphatase activities in Golgi-like vesicles. Proc. Natl. Acad. Sci. USA 86:69356939.

2. Aris, J. P., and G. Blobel. 1988. Identification and characterization of a yeast nucleolar protein that is similar to a rat liver nucleolar protein. J. Cell Biol. 107:17-31.
3. Bender, A., and G. F. Sprague, Jr. 1986. Yeast peptide pheromones, a-factor and $\alpha$-factor, activate a common response mechanism in their target cells. Cell 47:929-937.

4. Blinder, D., and D. D. Jenness. 1989. Regulation of postreceptor signaling in the pheromone response pathway of Saccharomyces cerevisiae. Mol. Cell. Biol. 9:3720-3726.

5. Blumer, K. J., J. E. Reneke, and J. Thorner. 1988. The STE2 gene product is the ligand-binding component of the $\alpha$-factor receptor of Saccharomyces cerevisiae. J. Biol. Chem. 263:10836-10842.

6. Blumer, K. J., and J. Thorner. 1990. $\beta$ and $\gamma$ subunits of a yeast guanine nucleotide-binding protein are not essential for membrane association of the $\alpha$ subunit but are required for receptor coupling. Proc. Natl. Acad. Sci. USA 87:4363-4367.

7. Boeke, J. D., F. LaCroute, and G. R. Fink. 1984. A positive selection for mutants lacking orotidine- 5 '-phosphate decarboxylase activity in yeast: 5-fluoro-orotic acid resistance. Mol. Gen. Genet. 197:345-346.

8. Burkholder, A. C., and L. H. Hartwell. 1985. The yeast $\alpha$-factor receptor: structural properties deduced from the sequence of the STE2 gene. Nucleic Acids Res. 13:8463-8475.

9. Cahn, F. H., and M. S. Fox. 1968. Fractionation of transformable bacteria from competent cultures of Bacillus subtilis on renografin gradients. J. Bacteriol. 95:867-875.

10. Cartwight, C. P., and D. J. Tipper. 1991. In vivo topological analysis of Ste2, a yeast plasma membrane protein, by using $\beta$-lactamase gene fusions. Mol. Cell. Biol. 11:2620-2628.

11. Chan, R. K. 1977. Recovery of Saccharomyces cerevisiae matingtype a cells from G1 arrest by $\alpha$ factor. J. Bacteriol. 130:766-774.

12. Chan, R. K., and C. A. Otte. 1982. Isolation and genetic analysis of Saccharomyces cerevisiae mutants supersensitive to G1 arrest by a factor and $\alpha$ factor pheromones. Mol. Cell. Biol. 2:11-20.

13. Chan, R. K., and C. A. Otte. 1982. Physiological characterization of Saccharomyces cerevisiae mutants supersensitive to G1 arrest by a factor and $\alpha$ factor pheromones. Mol. Cell. Biol. 2:21-29.

14. Chvatchko, Y., I. Howald, and H. Riezman. 1986. Two yeast mutants defective in endocytosis are defective in pheromone response. Cell 46:355-364.

15. Ciejek, E., and J. Thorner. 1979. Recovery of $S$. cerevisiae a cells from $\mathrm{G} 1$ arrest by $\alpha$-factor pheromone requires endopeptidase action. Cell 18:623-635.

16. Ciejek, E., J. Thorner, and M. Geier. 1977. Solid phase peptide synthesis of $\alpha$-factor, a yeast mating pheromone. Biochem. Biophys. Res. Commun. 78:952-961.

17. Clark, C. D., T. Palzkill, and D. Botstein. 1994. Systematic mutagenesis of the yeast mating pheromone receptor third intracellular loop. J. Biol. Chem. 269:8831-8841.

18. Clark, K. L., N. G. Davis, D. K. Wiest, J.-J. Hwang-Shum, and G. F. Sprague, Jr. 1988. Response of yeast $\alpha$ cells to a-factor pheromone: topology of the receptor and identification of a component of the response pathway. Cold Spring Harbor Symp. Quant. Biol. 53:611-620.

19. Davis, N. G., J. L. Horecka, and G. F. Sprague, Jr. 1993. cis- and trans-acting functions required for endocytosis of the yeast pheromone receptors. J. Cell Biol. 122:53-65.

20. Dietzel, C., and J. Kurjan. 1987. Pheromonal regulation and sequence of the Saccharomyces cerevisiae SST2 gene: a model for densensitization to pheromone. Mol. Cell. Biol. 7:4169-4177.

21. Dietzel, C., and J. Kurjan. 1987. The yeast $S C G 1$ gene: a $\mathrm{G}_{\alpha}$-like protein implicated in the a- and $\alpha$-factor response pathway. Cell 50:1001-1010.

22. Dohlman, H. G., J. Thorner, M. G. Caron, and R. J. Lefkowitz. 1991. Model systems for the study of seven-transmembranesegment receptors. Annu. Rev. Biochem. 60:653-688.

23. Franke, R. R., B. Konig, T. P. Sakmar, H. G. Khorana, and K. P. Hofmann. 1990. Rhodopsin mutants that bind but fail to activate transducin. Science 250:123-125.

24. Hagen, D. C., G. McCaffrey, and G. F. Sprague, Jr. 1986. Evidence the yeast STE3 gene encodes a receptor for the peptide pheromone a factor: gene sequence and implications for the structure of the presumed receptor. Proc. Natl. Acad. Sci. USA 83:1418-1422.

25. Hartig, A., J. Holly, G. Saari, and V. L. MacKay. 1986. Multiple regulation of $S T E 2$, a mating-type-specific gene of Saccharomyces cerevisiae. Mol. Cell. Biol. 6:2106-2114. 
26. Hartwell, L. H. 1967. Macromolecule synthesis in temperaturesensitive mutants of yeast. J. Bacteriol. 93:1662-1670.

27. Hartwell, L. H. 1980. Mutants of Saccharomyces cerevisiae unresponsive to cell division control by polypeptide mating hormone. J. Cell Biol. 85:811-822.

28. Jenness, D. D., A. C. Burkholder, and L. H. Hartwell. 1983. Binding of $\alpha$-factor pheromone to yeast a cells: chemical and genetic evidence for an $\alpha$-factor receptor. Cell 35:521-529.

29. Jenness, D. D., B. S. Goldman, and L. H. Hartwell. 1987. Saccharomyces cerevisiae mutants unresponsive to $\alpha$-factor pheromone: $\alpha$-factor binding and extragenic suppression. Mol. Cell. Biol. 7:1311-1319.

30. Jenness, D. D., and P. Spatrick. 1986. Down regulation of the $\alpha$-factor pheromone receptor in S. cerevisiae. Cell 46:345-353.

31. Jones, E. W. 1991. Three proteolytic systems in the yeast Saccharomyces cerevisiae. J. Biol. Chem. 266:7963-7966.

32. Kobilka, B. K., T. S. Kobilka, K. Daniel, J. W. Regan, M. G. Caron, and R. J. Lefkowitz. 1988. Chimeric $\alpha_{2^{-}}, \beta_{2^{-}}$-adrenergic receptors: delineation of domains involved in effector coupling and ligand binding specificity. Science 240:1310-1316.

33. Konopka, J. B. 1993. AFRI acts in conjunction with the $\alpha$-factor receptor to promote morphogenesis and adaptation. Mol. Cell. Biol. 13:6876-6888.

34. Konopka, J. B., D. D. Jenness, and L. H. Hartwell. 1988. The $\mathrm{C}$-terminus of the $S$. cerevisiae $\alpha$-pheromone receptor mediates an adaptive response to pheromone. Cell 54:609-620.

35. Kubler, E., and H. Riezman. 1993. Actin and fimbrin are required for the internalization step of endocytosis in yeast. EMBO J. 12:2855-2862.

36. Kurjan, J. 1985. $\alpha$-Factor structural gene mutations in Saccharomyces cerevisiae: effects on $\alpha$-factor production and mating. Mol. Cell. Biol. 5:787-796.

37. Laemmli, U. K. 1970. Cleavage of structural proteins during the assembly of the head of bacteriophage T4. Nature (London) 227:680-685.

38. Manolson, M. F., D. Proteau, R. A. Preston, A. Stenbit, B. T. Roberts, M. A. Hoyt, D. Preuss, J. Mulholland, D. Botstein, and E. W. Jones. 1992. The VPHI gene encodes a 95-kDa integral membrane polypeptide required for in vivo assembly and activity of the yeast vacuolar $\mathrm{H}^{+}$ATPase. J. Biol. Chem. 267:14294-14303.

39. Marsh, L., A. M. Neiman, and I. Herskowitz. 1991. Signal transduction during pheromone response in yeast. Annu. Rev. Cell Biol. 7:699-728.

40. Moore, S. A. 1983. Comparison of dose-response curves for $\alpha$-factor-induced cell divion arrest, agglutination, and projection formation of yeast cells. J. Biol. Chem. 258:13849-13856.

41. Moore, S. A. 1984. Yeast cells recover from mating pheromone $\alpha$-factor-induced division arrest by desensitization in the absence of $\alpha$-factor destruction. J. Biol. Chem. 259:1004-1010.

42. Nakafuku, M., H. Itoh, S. Nakamura, and Y. Kaziro. 1987. Occurrence in Saccharomyces cerevisiae of a gene homologous to the cDNA coding for the $\alpha$ subunit of mammalian G proteins. Proc. Natl. Acad. Sci. USA 84:2140-2144.

43. Nakayama, N., A. Miyajima, and K. Arai. 1985. Nucleotide sequences of $S T E 2$ and $S T E 3$, cell type-specific sterile genes from Saccharomyces cerevisiae. EMBO J. 4:2643-2648.

44. Neiman, A. M. 1993. Conservation and reiteration of a kinase cascade. Trends Genet. 9:390-394.

45. Raths, S., J. Rohrer, F. Crausaz, and H. Riezman. 1993. end3 and end4: two mutants defective in receptor-mediated and fluid-phase endocytosis in Saccharomyces cerevisiae. J. Cell Biol. 120:55-65.

46. Reneke, J. E. 1989. Ph.D. thesis. University of California, Berkeley.

47. Reneke, J. E., K. J. Blumer, W. E. Courchesne, and J. Thorner. 1988 . The carboxy-terminal segment of the yeast $\alpha$-factor receptor is a regulatory domain. Cell 55:221-234.

48. Riezman, H. 1993. Yeast endocytosis. Trends Cell Biol. 3:273-277.

49. Rohrer, J., H. Benedetti, B. Zanolari, and H. Riezman. 1993. Identification of a novel sequence mediating regulated endocytosis of the $\mathrm{G}$ protein-coupled $\alpha$-pheromone receptor in yeast. Mol. Biol. Cell 4:511-521.

50. Rose, M. D., and G. R. Fink. 1987. KARl, a gene required for function of both intranuclear and extranuclear microtubules in yeast. Cell 48:1047-1060.

51. Rothman, J. H., C. P. Hunter, L. A. Valls, and T. H. Stevens. 1986. Overproduction-induced mislocalization of a yeast vacuolar protein allows isolation of its structural gene. Proc. Natl. Acad. Sci. USA 83:3248-3252.

52. Rothstein, R. 1983. One-step gene disruption in yeast. Methods Enzymol. 101:202-211.

53. Sanders, S. L., K. M. Whitfield, J. P. Vogel, M. D. Rose, and R. W. Schekman. 1992. Sec61p and BiP directly facilitate polypeptide translocation into the ER. Cell 69:353-365.

54. Singer, B., and H. Riezman. 1990. Detection of an intermediate compartment involved in transport of $\alpha$-factor from the plasma membrane to the vacuole in yeast. J. Cell Biol. 110:1911-1922.

55. Singer-Kruger, B., R. Frank, F. Crausaz, and H. Riezman. 1993 Partial purification and characterization of early and late endosomes from yeast. J. Biol. Chem. 268:14376-14386.

56. Sprague, G. F., Jr., and I. Herskowitz. 1981. Control of yeast cell type by the mating type locus. I. Identification and control of expression of the a-specific gene BAR1. J. Mol. Biol. 153:305-321.

57. Sprague, G. F., Jr., and J. Thorner. 1992. Pheromone response and signal transduction during the mating process of Saccharomyces cerevisiae, p. 657-744. In J. R. Broach, J. R. Pringle, and E. W. Jones, (ed.), The molecular and cellular biology of the yeast Saccharomyces. Cold Spring Harbor Laboratory Press, Cold Spring Harbor, N.Y.

58. Tan, P. K., N. G. Davis, G. F. Sprague, and G. S. Payne. 1993. Clathrin facilitates the internalization of seven transmembrane segment receptors for mating pheromones in yeast. J. Cell Biol. 123:1707-1716.

59. Trowbridge, I. S., J. F. Collawn, and C. R. Hopkins. 1993. Signal-dependent membrane protein trafficking in the endocytic pathway. Annu. Rev. Cell Biol. 9:129-161.

60. Tschopp, J., and R. Schekman. 1983. Two distinct subfractions in isolated Saccharomyces cerevisiae plasma membranes. J. Bacteriol. 156:222-229.

61. Weiner, J. L., C. Guttierez-Steil, and K. J. Blumer. 1993. Disruption of receptor-G protein coupling in yeast promotes the function of an SST2-dependent adaptation pathway. J. Biol. Chem. 268: 8070-8077.

62. Whiteway, M., L. Hougan, D. Dignard, D. Y. Thomas, L. Bell, G. C. Saari, F. J. Grant, P. O'Hara, and V. L. MacKay. 1989. The STE4 and STE 18 genes of yeast encode potential $\beta$ and $\gamma$ subunits of the mating factor receptor-coupled G protein. Cell 56:467-477.

63. Zanolari, B., S. Raths, B. Singer-Kruger, and H. Riezman. 1992. Yeast pheromone receptor endocytosis and hyperphosphorylation are independent of $\mathrm{G}$ protein-mediated signal transduction. Cell 71:755-763. 